\title{
EFEKTIVITAS PENDEKATAN QUANTUM LEARNING DAN CONTEXTUAL TEACHING AND LEARNING (CTL) TERHADAP PRESTASI BELAJAR MATEMATIKA DITINJAU DARI POLA ASUH ORANG TUASISWA SMP DI KABUPATEN MAGETANTAHUN AJARAN 2012/2013
}

\author{
Restu Lusiana \\ IKIP PGRI Madiun, Kota Madiun
}

\begin{abstract}
ABSTRAK
Tujuan penelitian ini untuk mengetahui: (1) Manakah pendekatan pembelajaran yang memberikan prestasi belajar yang lebih baik, pendekatan Quantum Learning dengan metode diskusi, pendekatan Contextual Teaching and Learning (CTL) dengan metode diskusi, atau pembelajaran langsung. (2) Manakah prestasi belajar siswa yang lebih baik, siswa yang mempunyai tipe pola asuh otoriter, demokratis, atau permisif. (3) Pada masing-masing tipe pola asuh, manakah yang memberikan prestasi belajar lebih baik, pendekatan Quantum Learning dengan metode diskusi, pendekatan Contextual Teaching and Learning (CTL)dengan metode diskusi atau pembelajaran langsung. (4) Pada masing-masing pendekatan pembelajaran, manakah yang memberikan prestasi belajar lebih baik siswa dengan tipe pola asuh otoriter, demokratis, atau permisif. Penelitian ini menggunakan metode penelitian eksperimen semu (quasi experiment research) dengan menggunakan desain faktorial 3x3. Populasi pada penelitian ini adalah siswa kelas VII SMP Negeri di kabupaten Magetan tahun pelajaran 2012/2013. Teknik pengambilan sampel yang digunakan dalam penelitian ini adalah stratified cluster random sampling. Pengumpulan data dilakukan dengan metode dokumentasi, angket pola asuh orang tua, dan tes ptrestasi belajar. Teknik analisis data yang digunakan adalah analisis variansi dua jalan. Hasil Penelitian ini adalah (1) pembelajaran dengan pendekatan Quantum Learning menghasilkan prestasi belajar yang lebih baik dibandingkan pembelajaran dengan pendekatan CTL maupun pendekatan langsung, dan pembelajaran dengan pendekatan $C T L$ menghasilkan prestasi yang sama baik dengan pendekatan langsung. (2) Siswa dengan pola asuh orang tua otoriter menghasilkan prestasi belajar yang sama baik dengan pola asuh demokratis, siswa dengan pola asuh otoriter menghasilkan prestasi belajar yang sama baik dengan pola asuh permisif, dan siswa dengan pola asuh demokratis menghasilkan prestasi belajar yang lebih baik dibandingkan pola asuh permisif. (3) pada masing-masing tipe pola asuh orang tua otoriter, demokratis, maupun permisif, pendekatan pembelajaran Quantum Learning dengan metode diskusi menghasilkan prestasi belajar yang lebih baik daripada pendekatan pembelajaran CTL dengan metode diskusi maupun penggunaan pendekatan langsung, dan pendekatan pembelajaran CTL dengan metode diskusi menghasilkan prestasi belajar yang sama baik dengan pendekatan langsung. (4) pada masingmasing pendekatan pembelajaran Quantum Learning, CTL, maupun pembelajaran langsung, siswa dengan pola asuh orang tua otoriter memberikan prestasi sama baik dengan siswa dengan pola asuh orang tua demokratis, siswa dengan pola asuh orang tua otoriter memberikan prestasi sama baik dengan siswa dengan pola asuh orang tua permisif, dan siswa dengan pola asuh orang tua demokratis memberikan prestasi lebih baik daripada siswa dengan pola asuh orang tua permisif.
\end{abstract}

Kata Kunci: Quantum Learning, Contextual Teaching and Learning (CTL), Pola Asuh Orang Tua, Prestasi Belajar Matematika.

\section{PENDAHULUAN}

Pembelajaran matematika di tanah air saat ini sedang mengalami perubahan paradigma dari pembelajaran yang berpusat pada guru (teacher centered approach) menjadi pembelajaran yang berpusat pada siswa (student centered approach). Paradigma baru pembelajaran matematika lebih menekankan pada peserta didik sebagai manusia yang memiliki potensi untuk belajar 
dan berkembang. Siswa harus aktif dalam pencarian dan pengembangan pengetahuan. Guru harus mengubah perannya, tidak lagi sebagai pemegang otoritas tertinggi keilmuan dan indoktriner, tetapi menjadi fasilitator yang membimbing siswa ke arah pembentukan pengetahuan oleh diri mereka sendiri. Melalui paradigma baru tersebut diharapkan di kelas siswa aktif dalam belajar, aktif berdiskusi, berani menyampaikan gagasan dan menerima gagasan dari orang lain.

Dalam kenyataannya praktek pembelajaran matematika di Indonesia selama ini masih berpusat pada guru. Selain itu kebanyakan siswa di sekolah beranggapan bahwa belajar matematika tidak menyenangkan dan hanya menjadi rutinitas tanpa diiringi kesadaran untuk menambah wawasan. Meskipun matematika diajarkan dengan prosentase jam pelajaran yang lebih banyak, namun prestasi siswa dalam bidang matematika relatif rendah. Sejak dulu rendahnya prestasi belajar matematika siswa menjadi salah satu kekhawatiran di banyak negara termasuk Indonesia. Menurut penelitian Trend in International Mathematics and Science Study (TIMSS) tahun 2007 matematika Indonesia berada diperingkat 36 dari 48 negara (data UNESCO). Sementara dari hasil Programme for International Student Assesment (PISA) 2009, kualitas pembelajaran Indonesia berada pada peringkat 60 dari 65 negara untuk bidang matematika (www.oecd.org/ publishing/corrigenda)

Secara umum kondisi pembelajaran matematika di kabupaten Magetan belum seperti yang diharapkan, hal ini ditunjukkan dari rendahnya nilai matematika pada Ujian Nasional. Aritmatika sosial dan perbandingan adalah salah satu materi yang dipelajari siswa SMP kelas VII semester ganjil. Salah satu kesulitan siswa di kabupaten Magetan dalam materi ini adalah menyelesaikan masalah berkaitan dengan aritmatika sosial dan perbandingan. Hal ini terlihat dari data Badan Standar Nasional Pendidikan (BNSP) yang menunjukkan prosentase penguasaan materi soal matematika Ujian Nasional tahun pelajaran 2010/2011.

Berdasarkan sumber data dari bimbingan konseling, salah satu faktor dari luar yang mempengaruhi prestasi belajar siswa adalah peran keluarga sebagai pendidik. Pola asuh yang ditanamkan orang tua pada siswa akan membentuk suatu kepribadian, kebiasaan dan karakter yang melekat sampai dewasa. Hal ini bisa berdampak pada pada cara belajar yang pada akhirnya mempengaruhi prestasi belajar siswa.

Adapun pola asuh secara umum yang diterapkan orang tua yaitu, pola asuh otoriter yang ditandai dengan adanya paksaan dari orang tua, pola asuh demokratis ditandai dengan adanya pengarahan dari orang tua yang dilakukan secara musyawarah, serta pola asuh permisif ditandai dengan kebebasan yang berlebihan yang diberikan orang tua kepada anak. Pola asuh orang tua akan memberikan pengaruh terhadap prestasi belajar anak.

Prestasi belajar merupakan suatu bukti keberhasilan belajar atau kemampuan seorang siswa dalam melakukan kegiatan belajar sesuai dengan bobot yang dicapainya (Winkel, 1996:162). Prestasi belajar siswa dalam bidang matematika masih relatif rendah. Keadaan ini menunjukkan bahwa selama ini guru dalam pembelajarannya masih belum banyak membuat inovasi baru dalam pembelajaran. Pendekatan dan metode pembelajaran yang sudah diterapkan di Indonesia begitu banyak, namun belum optimal dalam pelaksanaannya. Guru masih bingung untuk menerapkan pendekatan dan metode pembelajaran yang baik untuk peserta didiknya, padahal siswa mempunyai cara belajar yang variatif sehingga pendekatan langsung sudah tidak sesuai untuk diterapkan. 
Beberapa pendekatan pembelajaran yang dipandang efektif untuk mempercepat pencapaian kompetensi dasar peserta didik adalah pendekatan Quantum Learning. Quantum Learning, pendekatan ini dilakukan dengan mengubah bermacam-macam interaksi, hubungan, dan inspirasi yang ada di dalam dan di luar lingkungan belajar (Deporter \& Hernacki, 2010). Lingkungan belajar yang menyenangkan akan mampu menggabungkan percaya diri, keterampilan belajar, dan keterampilan berkomunikasi. Dengan metode belajar yang tepat, siswa dapat meraih prestasi belajar berlipat ganda. Salah satu konsep dasarnya adalah bahwa belajar itu harus mengasyikkan dan berlangsung dalam suasana gembira, sehingga pintu masuk untuk informasi baru akan lebih lebar dan terekam dengan baik (Baharrudin \& Nur, 2010:135). Pendekatan pembelajaran yang lain adalah Contextual Teaching and Learning atau biasa disingkat CTL. Pembelajaran dan pengajaran kontekstual merupakan konsep pembelajaran yang menekankan pada keterkaitan antara materi pembelajaran dengan dunia kehidupan nyata, sehingga siswa mampu menghubungkan dan menerapkan kompetensi hasil belajar dengan kehidupan sehari-hari (Amri \& Ahmadi, 2010:193). Sedangkan oleh Johnson CTL digambarkan sebagai berikut:

$$
\text { “...an educational process that aims }
$$

to help students see meaning in the academic material they are studying by connecting academic subjects with the context of their daily lives, that is, with context of their personal, social, ang cultural circumstance. To achieve this aim, the system encompasses the following eight components making meaningful conections, doing significant work, self-regulated learning, collaborating, critical and creative thinking, nurturing the individual, reaching high standarts, using authentic assessment."

Kutipan tersebut menegaskan hakikat $C T L$ yang dapat diringkas dalam tiga kata, yaitu, makna, bermakna, dan dibermaknakan. CTL adalah sebuah sistem yang merangsang otak untuk menyusun pola-pola yang mewujudkan makna. (Johnson, 2010:57). Suatu pendekatan pembelajaran tidak dapat berjalan apabila tidak ada suatu metode pembelajaran yang digunakan sebagai penunjang, untuk itu dalam penelitian ini penulis menggunakan metode pembelajaran diskusi untuk menunjang berjalannya pendekatan pembelajaran. Yang dimaksud metode diskusi adalah suatu kegiatan kelompok dalam memecahkan masalah untuk mengambil kesimpulan. Diskusi tidak sama dengan berdebat, diskusi selalu diarahkan kepada pemecahan masalah yang menimbulkan berbagai macam pendapat dan akhirnya diambil suatu kesimpulan yang dapat diterima oleh anggota dalam kelompoknya (Ahmadi, 2007:114).

Tujuan yang diharapkan dapat diperoleh melalui penelitian ini adalah: (1) Untuk mengetahui pendekatan pembelajaran yang memberikan prestasi belajar yang lebih baik, pendekatan Quantum Learning dengan metode diskusi, pendekatan Contextual Teaching and Learning (CTL) dengan metode diskusi, atau pembelajaran langsung. (2) Untuk mengetahui prestasi belajar siswa yang lebih baik, siswa yang mempunyai tipe pola asuh otoriter, demokratis, atau permisif.

(3) Untuk mengetahui pada masing-masing tipe pola asuh, yang memberikan prestasi belajar lebih baik, pendekatan Quantum Learning dengan metode diskusi, pendekatan Contextual Teaching and Learning (CTL)dengan metode diskusi atau pembelajaran langsung. (4) Untuk mengetahui pada masing-masing pendekatan pembelajaran, yang memberikan prestasi belajar lebih baik siswa dengan tipe pola asuh otoriter, demokratis, atau permisif.

\section{METODE PENELITIAN}

Penelitian ini dilaksanakan pada SMP Negeri se-kabupaten Magetan, dan subjek penelitiannya adalah siswa kelas VII 
semester ganjil tahun pelajaran 2012/2013. Penelitian ini dibagi dalam beberapa tahap. Tahap-tahap dalam pelaksanaan penelitian adalah: tahap perencanaan, tahap pelaksanaan, tahap penyelesaian, dan tahap penyusunan laporan.

Jenis penelitian ini adalah penelitian eksperimen semu (quasi experimental research). Tujuan penelitian eksperimental semu adalah untuk memperoleh informasi yang merupakan perkiraan bagi informasi yang dapat diperoleh dengan eksperimen yang sebenarnya dalam keadaan yang tidak memungkinkan untuk mengontrol dan/atau memanipulasi semua variabel yang relevan (Budiyono, 2003:82-83). Dalam penelitian ini, responden dikelompokkan menjadi tiga kelompok. Kelompok pertama adalah kelompok eksperimen satu, yaitu siswa yang mendapat perlakuan pembelajaran matematika menggunakan pendekatan Quantum Learning dengan metode diskusi. Kelompok kedua adalah kelompok eksperimen dua, yaitu siswa yang mendapat perlakuan pembelajaran matematika menggunakan pendekatan CTL dengan metode diskusi. Kelompok tiga adalah kelompok kontrol, yaitu siswa yang mendapat perlakuan pembelajaran matematika dengan pembelajaran langsung. Desain faktorial yang digunakan dalam penelitian ini adalah:

Tabel 1. Desain Faktorial 3x3

\begin{tabular}{cccc} 
(B) Pola Asuh Orang Tua & $\begin{array}{c}\text { Otoriter } \\
\left(b_{1}\right)\end{array}$ & $\begin{array}{c}\text { Demokr } \\
\text { atis }\end{array}$ & \multicolumn{2}{c}{$\begin{array}{c}\text { Permis } \\
\text { if }\end{array}$} \\
(A) Pendekatan pembelajaran & & $\left(b_{2}\right)$ & $\left(b_{3}\right)$ \\
\hline Quantum Learning $\left(a_{1}\right)$ & $A B_{11}$ & $A B_{12}$ & $A B_{13}$ \\
\hline CTL $\left(a_{2}\right)$ & $A B_{21}$ & $A B_{22}$ & $A B_{23}$ \\
\hline Langsung $\left(a_{3}\right)$ & $A B_{31}$ & $A B_{32}$ & $A B_{33}$ \\
\hline
\end{tabular}

Dalam penelitian ini, yang menjadi populasi adalah siswa kelas VII SMP Negeri di sekabupaten Magetan tahun pelajaran 2012/2013. Menurut Budiyono (2009:121) populasi adalah keseluruhan pengamatan yang ingin diteliti. Sampel dari penelitian ini diambil dua kelompok, yaitu kelompok kontrol dan kelompok eksperimen. Kelompok kontrol menggunakan pembelajaran langsung sedangkan kelas eksperimen menggunakan pendekatan Quantum Learning dengan metode diskusi dan pendekatan Contextual Teaching and Learning (CTL) dengan metode diskusi.

Teknik pengambilan sampel dilakukan dengan cara stratified cluster random sampling. Tahapan yang dilakukan dalam pengambilan sampel yaitu seluruh SMP Negeri yang ada di kabupaten Magetan terlebih dahulu dikelompokkan ke dalam tingkatan-tingkatan, yaitu kategori kelompok tinggi, sedang dan rendah. Pengelompokan tersebut berdasarkan rerata nilai total pada Ujian Nasional SMP Negeri sekabupaten Magetan tahun pelajaran 2010/2011.

Sampel diambil secara acak, masingmasing sekolah mewakili satu kelompok berdasarkan rerata nilai ujian nasional tahun pelajaran 2010/2011. Dalam penelitian ini sekolah yang mewakili kelompok tinggi adalah SMPN 1 Magetan, kelompok sedang adalah SMPN 4 Magetan, dan kelompok rendah adalah SMPN 2 Sukomoro Magetan.

Variabel penelitian merupakan hal yang sangat penting karena dengan adanya variabel dapat ditentukan teknik analisis data yang digunakan. Variabel adalah konstrukkonstruk/sifat-sifat yang diteliti atau sesuatu yang menggolongkan angota-anggota kelompok ke dalam beberapa golongan atau suatu sifat yang dapat memiliki bermacam nilai/harga (Budiyono, 2009:4). Dalam 
penelitian ini ada 2 variabel, yaitu variabel bebas dan terikat. Variabel bebas (independent variable) adalah variabel yang memberi pengaruh. Dalam penelitian ini variabel bebasnya adalah pendekatan pembelajaran dan pola asuh orang tua, sedangkan variabel terikat dalam penelitian ini adalah prestasi belajar matematika.

Metode pengumpulan data yang digunakan dalam penelitian ini antara lain metode dokumentasi, tes prestasi belajar, dan angket pola asuh orang tua. Instrumen yang digunakan dalam penelitian ini berupa tes dan angket untuk memperoleh data tentang prestasi belajar matematika dan jenis pola asuh orang tua siswa. Sebelum instrumen tes digunakan, terlebih dahulu diuji cobakan kemudian dilakukan juga analisis instrumen untuk mengetahui validitas dan reabilitas instrumen tes tersebut. Sedangkan untuk instrumen angket dilakukan analisis instrumen dengan validitas isi dari beberapa validator terlebih dahulu agar butir soal yang digunakan dalam angket benar-benar baik. Angket yang digunakan dalam penelitian ini tidak di uji cobakan karena merupakan angket pemilahan dan tidak terdapat skor didalamnya, sehingga tidak dilakukan uji konsistensi internal dan uji reliabilitas.

Setelah data diperoleh dari pelaksanaan penelitian, yang dilaksanakan selanjutnya adalah pengujian terhadap data tersebut, adapun pengujian data adalah: uji normalitas menggunakan metode Lilliefors, uji homogenitas dengan uji Bartlett, uji keseimbangan, uji hipotesis, dan uji komparasi ganda menggunakan metode Scheffe'.

\section{HASIL PENELITIAN}

Proses pembelajaran dilakukan dengan menggunakan pendekatan Quantum Learning pada kelompok eksperimen pertama, menggunakan pendekatan Contextual Teaching and Learning (CTL) pada kelompok eksperimen kedua, serta pendekatan langsung pada kelompok kontrol. Setelah proses pembelajaran berakhir, diberikan tes prestasi belajar kepada siswa untuk materi aritmatika sosial dan perbandingan. Data hasil tes prestasi belajar matematika, dan rata-rata prestasi belajar matematika berdasarkan pendekatan pembelajaran dan pola asuh orang tua dapat dilihat pada Tabel 2.

Tabel 2. Rata-rata Tes Prestasi Belajar Matematika Siswa di dalam Pembelajaran dan Pola Asuh Orang Tua

\begin{tabular}{ccccc}
\hline \multirow{2}{*}{ Pembelajaran } & \multicolumn{2}{c}{ Rata-rata Tes Prestasi Belajar Siswa } & \multirow{2}{*}{ Berdasarkan Pola Asuh Orang Tua } & \multirow{2}{*}{ Rata-rata Tes } \\
\cline { 2 - 4 } & Otoriter & Demokratis & Permisif & \\
\hline Quantum Learning & 79,0000 & 82,1714 & 73,0435 & 78,0716 \\
\hline CTL & 73,7143 & 79,6923 & 67,6000 & 73,6689 \\
\hline Pembelajaran Langsung & 69,2800 & 70,3333 & 70,8000 & 70,1378 \\
\hline Rata-rata Tes & 73,9981 & 77,3990 & 70,4812 & 221,8783 \\
\hline
\end{tabular}

Setelah dilakukan uji normalitas dan uji homogenitas variansi sebagai syarat untuk analisis variansi dan diperoleh semua populasi berdistribusi normal dan variansi populasi siswa homogen, maka dapat dilanjutkan ke uji selanjutnya yaitu analisis variansi. Pada penelitian ini analisis variansi yang digunakan adalah analisis variansi dua jalan dengan sel tak sama dengan taraf signifikansi $5 \%$. Analisis variansi dua jalan dengan sel tak sama dan perhitungannya, diperoleh hasil pada Tabel 3. 
Tabel 3. Rangkuman Analisis Variansi Dua Jalan dengan Sel Tak Sama

\begin{tabular}{ccccccc}
\hline Sumber & $J K$ & $d k$ & $R K$ & $F_{\text {obs }}$ & $F$ tabel & Keputusan Uji \\
\hline $\begin{array}{c}\text { Pembelajaran } \\
(A)\end{array}$ & 2405,0218 & 2 & 1202,5109 & 9,7828 & 3,00 & $H_{0}$ ditolak \\
\hline $\begin{array}{c}\text { Pola Asuh } \\
\text { Orang Tua }(B)\end{array}$ & 1821,3396 & 2 & 910,6698 & 7,4086 & 3,00 & $H_{0}$ ditolak \\
\hline $\begin{array}{c}\text { Interaksi } \\
(A B)\end{array}$ & 1154,0198 & 4 & 288,5049 & 2,3471 & 2,37 & $H_{0}$ diterima \\
\hline Galat & 28763,5614 & 234 & 122,9212 & & & \\
\hline Total & 34143,9425 & 242 & & & & \\
\hline
\end{tabular}

Dari tabel di atas terlihat bahwa $H_{0} A$ ditolak, $H_{0} B$ ditolak, dan $H_{0} A B$ diterima. Kesimpulannya adalah sebagai berikut:

1. Pada efek utama $(A), H_{0} A$ ditolak. Hal ini berarti terdapat perbedaan prestasi belajar siswa yang menggunakan pendekatan Quantum Learning dengan metode diskusi, pendekatan CTL dengan metode diskusi, dan pendekatan langsung.

2. Pada efek utama $(B), H_{0} B$ ditolak. Hal ini berarti terdapat perbedaan prestasi belajar siswa yang memiliki pola asuh orang tua otoriter, demokratis, dan permisif.
3. Pada efek interaksi $(A B), H_{0} A B$ diterima. Hal ini berarti tidak terdapat interaksi antara pendekatan pembelajaran dan pola asuh orang tua terhadap prestasi belajar matematika siswa pada materi aritmatika sosial dan perbandingan.

Dari hasil perhitungan uji analisis variansi di atas, $H_{0} A$ ditolak. Untuk mengetahui pendekatan pembelajaran mana yang berbeda maka perlu dilakukan uji komparasi ganda antar baris. Rangkuman uji komparasi ganda antar baris dapat disajikan pada Tabel 4.

Tabel 4. Rangkuman Uji Komparasi Ganda Prestasi Belajar Matematika antar Pembelajaran

Komparasi $\left(\bar{X}_{i}-\bar{X}_{j} \cdot\left(\frac{1}{n_{i}}+\frac{1}{n_{j}}\right) \quad R K G \quad F \quad\right.$ Kritik $\quad$ Keputusan

\begin{tabular}{ccccccc}
\hline$\mu_{1 .}=\mu_{2 .}$ & 12,4687 & 0,0247 & $\begin{array}{c}122,92 \\
12\end{array}$ & 6,4259 & 6,0000 & $H_{0}$ Ditolak \\
\hline$\mu_{1 .}=\mu_{3 .}$ & 62,9452 & 0,0245 & $\begin{array}{c}122,92 \\
12\end{array}$ & 20,8667 & 6,0000 & $H_{0}$ Ditolak \\
\hline$\mu_{2 .}=\mu_{3 .}$ & 19,3838 & 0,0248 & $\begin{array}{c}122,92 \\
12\end{array}$ & 4,0826 & 6,0000 & $H_{0}$ Diterima \\
\hline
\end{tabular}

Berdasarkan Tabel 4, diperoleh rataan antar masing-masing sel pada baris pertama ditolak maka ada perbedaan signifikan antar rataan marginal untuk kelompok eksperimen Quantum Learning sebesar 78,0716 dan rataan marginal untuk kelompok eksperimen CTL sebesar 73,6689, maka dapat disimpulkan bahwa prestasi belajar matematika siswa dengan pendekatan Quantum Learning lebih baik daripada prestasi belajar matematika siswa dengan pendekatan CTL. Rataan antar masingmasing sel pada baris kedua ditolak maka ada perbedaan signifikan antar rataan marginal untuk kelompok eksperimen Quantum Learning sebesar 78,0716 dan rataan marginal untuk kelompok kontrol pembelajatran langsung sebesar 70,1378, maka dapat disimpulkan bahwa prestasi belajar matematika siswa dengan Quantum 
Learning lebih baik daripada prestasi belajar matematika siswa dengan pendekatan langsung. Rataan antar masing-masing sel pada baris ketiga diterima maka tidak ada perbedaan signifikan antar rataan marginal untuk kelompok eksperimen CTL sebesar 73,6689 dan rataan marginal untuk kelompok kontrol pembelajaran langsung sebesar 70,1378, maka dapat disimpulkan bahwa prestasi belajar matematika siswa dengan pendekatan $C T L$ sama baik dengan prestasi belajar matematika siswa dengan pendekatan langsung.

Pembahasan di atas memiliki kesamaan dengan penelitian yang dilakukan oleh Hary (2011) dan Kusno \& Joko (2011) yang menyimpulkan bahwa prestasi belajar siswa dengan Quantum Learning lebih baik dibandingkan dengan pembelajaran konvensional. Sedangkan prestasi belajar matematika siswa dengan pendekatan $C T L$ sama baik dengan prestasi belajar matematika siswa dengan pendekatan langsung, dikarenakan siswa belum terbiasa menggunakan pendekatan $C T L$ dalam proses pembelajaran. Dalam proses pembelajaran siswa belum dapat mengaitkan meteri pembelajaran dengan kehidupan nyata, dan siswa masih kesulitan untuk menghubungkan dan menerapkan kompetensi hasil belajar dengan kehidupan sehari-harinya. Hal ini berbeda dengan penelitian relevan yang dilakukan oleh Glynn \& Winter (2004) yang menyatakan bahwa penerapan strategi $C T L$ menunjukkan hasil yang baik ketika digunakan guru dalam proses pembelajaran dibandingkan pembelajaran konvensional.

Dari hasil perhitungan uji analisis variansi di atas, $H_{0} B$ ditolak. Untuk mengetahui pola asuh orang tua mana yang berbeda maka perlu dilakukan uji komparasi ganda antar kolom. Rangkuman uji komparasi ganda antar kolom disajikan pada Tabel 5.

Tabel 5. Rangkuman Uji Komparasi Ganda Prestasi Belajar Matematika antar Pola Asuh Orang Tua

\begin{tabular}{ccccccc}
\hline Komparasi & $\left(\bar{X}_{i}-\bar{X}_{j}\right)^{2}$ & $\left(\frac{1}{n_{i}}+\frac{1}{n_{j}}\right)$ & $R K G$ & $F$ & Kritik & Keputusan \\
\hline$\mu_{\cdot 1}=\mu_{\cdot 2}$ & 11,5661 & 0,0234 & $\begin{array}{c}122,921 \\
2\end{array}$ & 4,0252 & 6,0000 & $H_{0}$ Diterima \\
\hline$\mu \cdot 1=\mu_{\cdot 3}$ & 12,3685 & 0,0302 & $\begin{array}{c}122,921 \\
2\end{array}$ & 3,3365 & 6,0000 & $H_{0}$ Diterima \\
\hline$\mu \cdot 2=\mu_{\cdot 3}$ & 47,8560 & 0,0250 & $\begin{array}{c}122,921 \\
2\end{array}$ & 15,5957 & 6,0000 & $H_{0}$ Ditolak \\
\hline
\end{tabular}

Berdasarkan Tabel 5, diperoleh rataan antar masing-masing sel pada kolom pertama diterima maka tidak ada perbedaan signifikan antar rataan marginal untuk kelompok siswa dengan pola asuh otoriter sebesar 73,9981 dan rataan marginal untuk siswa dengan pola asuh orang tua demokratis sebesar 77,3990, maka dapat disimpulkan bahwa prestasi belajar matematika siswa dengan pola asuh demokratis sama baik dengan prestasi belajar matematika siswa dengan pola asuh orang tua otoriter. Rataan antar masing-masing sel pada kolom kedua diterima maka tidak ada perbedaan signifikan antar rataan marginal untuk kelompok siswa dengan pola asuh orang tua otoriter sebesar 73,9981 dan rataan marginal untuk kelompok siswa dengan pola asuh orang tua permisif sebesar 70,4812, maka dapat disimpulkan bahwa prestasi belajar matematika siswa dengan pola asuh orang tua otoriter sama baik dengan prestasi belajar matematika siswa dengan pola asug 
orang tua permisif. Rataan antar masingmasing sel pada kolom ketiga ditolak maka ada perbedaan signifikan antar rataan marginal untuk kelompok siswa dengan pola asuh orang tua demokratis sebesar 77,3990 dan rataan marginal untuk kelompok siswa dengan pola asuh orang tua permisif sebesar 70,4812, maka dapat disimpulkan bahwa prestasi belajar matematika siswa dengan pola asuh orang tua demokratis lebih baik daripada prestasi belajar matematika siswa dengan pola asug orang tua permisif.

Pada penelitian yang dilakukan oleh Rinaldi \& Howe (2012) yang menyatakan bahwa dari tiga jenis pola asuh orang tua berpengaruh terhadap perilaku dan prestasi anak, baik yang bersifat positif maupun negatif sehingga tiap-tiap jenis pola asuh memberikan pengaruh yang berbeda terhadap prestasi anak. Hal ini berbeda dengan hasil penelitian ini yang menyatakan hanya terdapat perbedaan prestasi belajar siswa dengan pola asuh demokratis dan permisif, sedangkan prestasi belajar siswa dengan pola asuh otoriter sama dengan pola asuh demokratis, dan prestasi belajar siswa dengan pola asuh otoriter sama dengan pola asuh permisif.

Dari analisis variansi dua arah diputuskan bahwa $H_{0} A B$ diterima, sehingga tidak perlu dilakukan uji lanjut pasca analisis variansi dengan metode Scheffe' untuk analisis variansi dua jalan. Berdasarkan kesimpulan hipotesis antar baris dan hipotesis antar kolom, maka dapat disimpulkan:

1. berdasarkan tipe pola asuh orang tua, menunjukkan prestasi belajar matematika siswa dengan pendekatan Quantum Learning lebih baik dibandingkan dengan prestasi belajar matematika siswa dengan pembelajaran yang menggunakan pendekatan CTL maupun pendekatan langsung. Prestasi belajar matematika yang diperoleh siswa dengan pendekatan CTL sama jika dibandingkan dengan prestasi belajar matematika dengan pendekatan langsung.
2. Berdasarkan jenis pembelajaran, menunjukkan prestasi belajar matematika siswa dengan pola asuh otoriter sama baik dengan prestasi belajar matematika siswa dengan pola asuh demokratis. Prestasi belajar matematika siswa dengan pola asuh otoriter sama baik dengan prestasi belajar matematika siswa dengan pola asuh permisif. Prestasi belajar matematika siswa dengan pola asuh demokratis lebih baik dibandingkan prestasi belajar siswa dengan pola asuh permisif.

\section{KESIMPULAN DAN SARAN}

Berdasarkan kajian teori dan didukung adanya analisis serta mengacu pada perumusan masalah yang telah diuraikan di atas, dapat disimpulkan beberapa hal sebagai berikut:

1. Pada materi aritmatika sosial dan perbandingan, penggunaan pendekatan pembelajaran Quantum Learning dengan metode diskusi menghasilkan prestasi belajar yang lebih baik daripada penggunaan pendekatan pembelajaran CTL dengan metode diskusi maupun penggunaan pendekatan langsung. Penggunaan pendekatan pembelajaran CTL dengan metode diskusi menghasilkan prestasi belajar yang sama baik dengan penggunaan pendekatan langsung.

2. Pada materi aritmatika sosial dan perbandingan, siswa dengan pola asuh orang tua otoriter memberikan prestasi sama baik dengan siswa dengan pola asuh orang tua demokratis. Siswa dengan pola asuh orang tua otoriter memberikan prestasi sama baik dengan siswa dengan pola asuh orang tua permisif. Siswa dengan pola asuh orang tua demokratis memberikan prestasi lebih baik daripada siswa dengan pola asuh orang tua permisif.

3. Pada materi aritmatika sosial dan perbandingan, pada masing-masing tipe pola asuh orang tua otoriter, demokratis, maupun permisif, penggunaan pendekatan 
pembelajaran Quantum Learning dengan metode diskusi menghasilkan prestasi belajar yang lebih baik daripada penggunaan pendekatan pembelajaran CTL dengan metode diskusi maupun penggunaan pendekatan langsung, dan penggunaan pendekatan pembelajaran CTL dengan metode diskusi menghasilkan prestasi belajar yang sama baik dengan penggunaan pendekatan langsung.

4. Pada materi aritmatika sosial dan perbandingan, pada masing-masing pendekatan pembelajaran Quantum Learning, CTL, maupun pembelajaran langsung, siswa dengan pola asuh orang tua otoriter memberikan prestasi sama baik dengan siswa dengan pola asuh orang tua demokratis, siswa dengan pola asuh orang tua otoriter memberikan prestasi sama baik dengan siswa dengan pola asuh orang tua permisif, dan siswa dengan pola asuh orang tua demokratis memberikan prestasi lebih baik daripada siswa dengan pola asuh orang tua permisif.

Berdasarkan pada kesimpulan di atas, maka disampaikan beberapa saran sebagai berikut:

1. Kepada Siswa: Pada pembelajaran Quantum Learning, siswa diharapkan selalu memperhatikan pengarahan guru dan berusaha memperoleh pengetahuannya sendiri melalui pengalaman belajar yang diberikan dalam suasana belajar yang menyenangkan, sedangkan pada pembelajaran $C T L$, siswa diharapkan selalu memperhatikan penjelasan dan pendapat dari siswa lain, baik dalam diskusi kelompok maupun keika kelompok lain mempresentasikan hasil kerjanya. Ketika berdiskusi dalam kelompok untuk memecahkan masalah, siswa hendaknya mengembangkan kerjasama dan kemauan untuk terlibat secara penuh dalam diskusi.
2. Kepada Guru: Guru sebaiknya memperhatikan potensi yang dimiliki siswa, sehingga mampu memilih pendekatan pembelajaran yang paling sesuai untuk diterapkan dalam proses pembelajaran. Misalnya dengan menggunakan pendekatan Quantum Learning, karena dalam hasil penelitian menyatakan bahwa pendekatan Quantum Learning memberikan prestasi belajar yang lebih baik dibandingkan pendekatan CTL maupun langsung.

3. Kepada kepala Sekolah: Dalam rangka menambah wawasan dan kompetensi guru dalam dunia kependidikan, terutama yang berkaitan dengan proses pembelajaran matematika, maka hendaknya kepala sekolah secara aktif menghimbau guru matematika untuk mengikuti diskusi, seminar, pelatihan, maupun kegiatan ilmiah kependidikan.

4. Kepada Orang Tua: Orang tua diharapkan memberikan pola asuh yang baik terhadap anak, supaya anak merasa dibimbing dengan baik, tidak merasa tertekan, dan merasa diperhatikan, sehingga diharapkan prestasi belajar anak akan menjadi lebih baik.

5. Kepada Peneliti Lain: Bagi para peneliti lain diharapkan dapat melakukan penelitian lebih lanjut terkait dengan pendekatan pembelajaran dan pola asuh orang tua sehingga diperoleh pendekatan dan metode pembelajaran yang efektif untuk diterapkan pada siswa dengan pola asuh orang tua yang berbeda.

\section{DAFTAR RUJUKAN}

Ahmadi, A.. 2007. Sosiologi Pendidikan. Jakarta: PT. Rineka Cipta. Jakarta: PT. Prestasi Pustakarya.

Amri, S. \& Ahmadi, I. K.. 2010. Kontruksi Pengembangan Pembelajaran. Jakarta: PT. Prestasi Pustakarya

Baharuddin dan Nur, E.. 2010. Teori belajar dan Pembelajaran. Jogjakarta: ArRuzz Media. 
Budiyono. 2003. Metodologi Penelitian. Surakarta: Sebelas Maret University Press.

2009. Statistika Untuk
penelitian. Surakarta: sebelas Maret University Press.

DePorter, B dan Hernacki, M.. 2010. Quantum Learning: membiasakan Belajar Nyaman dan Menyenangkan. Bandung: Kaifa.

Glynn, S.M. \& Winter, L.K.. 2004. Contextual Teaching and Learning of science in elementary schools. Journal of elementary science education A. Vol. 16, no. 2, pp. 5163. ISSN-1090-185X. Diunduh http://www.eric.ed.gov. $\quad$ Pada tanggal 15 Mei 2012 pukul 22.50 WIB.

Hary, A.. 2011. Efektifitas Pembelajaran Matematika dengan Menggunakan Pendekatan Quantum Learning dan Contextual Teaching and Learning Pada Pokok Bahasan Statistika Ditinjau dari Kreativitas peserta Didik SMA di Kota Palangkaraya. Surakarta: Pasca Sarjana UNS.
Johnson, E. B.. 2010. CTL Contextual teaching \& Learning Menjadikan Kegiatan Belajar-Mengajar Mengasyikkan dan Bermakna. Bandung: kaifa.

Kusno dan Joko. 2011. Effectiveness of Quantum Learning for Teaching Linear Program at the Muhammadiyah Senior High School of Purwokerto in Central Java Indonesia. International Journal for ducational Studies. Vol. 4, no. 1. Diunduh www.educareijes.com. Pada tanggal $18 \mathrm{Mei}$ 2012 pukul 21.50.

Rinaldi, C. M. \& Howe, N.. 2012. Mothers' and Fathers' Parenting Styles and Associations with Toddlers' Externalizing, Internalizing, and Adaptive Behaviors. Vol. 27, no. 2, p266-273. Early Childhood Research Quarterly. Diunduh http://www.sciencedirect.com. Pada tanggal 19 mei 2012 pukul 21.45.

Winkel, W. S.. 1996. Psikologi Pendidikan dan Evaluasi Belajar. Jakarta: PT Gramedia 